\title{
Correction to: Data Science and Its Applications to Social Research
}

\author{
Corrado Crocetta $^{1} \cdot$ Maurizio Carpita $^{2} \cdot$ Paola Perchinunno $^{3}$
}

Published online: 8 October 2021

(c) Springer Nature B.V. 2021

\section{Correction to: Social Indicators Research (2021) 156:339-340 https://doi.org/10.1007/s11205-021-02634-6}

In the original publication of this article was published under open access miskatenly and now the same has been retrospected.

Publisher's Note Springer Nature remains neutral with regard to jurisdictional claims in published maps and institutional affiliations.

The original article can be found online at https://doi.org/10.1007/s11205-021-02634-6.

Corrado Crocetta

corrado.crocetta@unifg.it

Maurizio Carpita

maurizio.carpita@unibs.it

Paola Perchinunno

paola.perchinunno@uniba.it

1 Department of Economics, University of Foggia, Foggia, Italy

2 Department of Economics and Management, University of Brescia, Brescia, Italy

3 Department of Economics, Management and Business Law, University of Bari A. Moro, Bari, Italy 